\title{
Reshaping the University Curriculum through the Visiting Lectureship
}

\author{
Valentyna I. Bobrytska \\ National Pedagogical Dragomanov University, Kyiv, Ukraine \\ http://orcid.org/0000-0002-1742-0103 \\ Hanna V. Krasylnykova \\ Khmelnytskyi National University, Khmelnytskyi, Ukraine \\ https://orcid.org/0000-0002-4846-722X \\ Nina G. Batechko \\ National University of Life and Environmental Science of Ukraine, \\ Kyiv, Ukraine \\ https:// orcid.org/0000-0002-3772-4489
}

\author{
Nataliia A. Beseda \\ National University "Yuri Kondratyuk Poltava Polytechnic", Poltava, Ukraine \\ http://orcid.org/0000-0002-1454-1938 \\ Yevheniy S. Spitsyn \\ Taras Shevchenko National University of Kyiv, Kyiv, Ukraine \\ http://orcid.org/0000-0001-8385-4789
}

\begin{abstract}
The purpose of the study is to investigate how visiting lectureship is capable to reshape and improve the university curriculum for four different majors such as educational policy, instruction, healthcare, and technology. The research is significant because it addresses some current challenges forming a crisis of higher education such as an instructional challenge, a fiscal challenge, a birth rate-related challenge, and a graduate employment challenge. This study combines exploratory and quasi-experimental research methods, and Baseline Study Survey Questionnaires (BSSQ), Questionnaire to Measure Research Skills (QMRS), The students' research activeness checklist, Professional Self-development Critical Reflection Scale (PSCRS), along with Self-directed Learning Skills Scale (SLSS) are the research instruments used in this study. The sample used are 184 (169 students and 15 lecturers), and key data are drawn from the assessment of students' research skills and activeness, professional self-development, self-directed learning and self-education skills, and professional socialisation by students themselves and their teachers before and after the intervention. The stakeholders' perceptions of visiting lectureship such as students,
\end{abstract}


lecturers, and representatives of the host organisations are studied using the focus group interviews. It is found that visiting lectureship reshapes and improves the university curriculum of four different majors namely: educational policy, instruction, healthcare, and technology. Add to this, visiting lectureship positively influences students' research activeness, professional self-development, selfdirected learning \& self-education skills, and professional socialisation, and it is positively perceived by students, lecturers, and representatives of the host organisations. Visiting lectureship also increases lecturers' motivation to provide a higher quality of instruction. Besides, it benefits the potential employers as these are involved in the educational process at the early stage of the programme in its design and updating, which will result in a more competent and competitive staff for them to hire.

Keywords: Higher education institutions; Visiting lectureship; University curriculum; Professional training

\section{Introduction}

Visiting or guest lectureship and professorship are becoming trendy at universities for two main reasons. First, it seems economically advantageous because a short-term contract basis of the invited experts and professors is less costly and more flexible for the institutions, and second, it provides the students the opportunity to learn from those who practically succeeded in the students' future professional field (Bobrytska, 2017; Leventhal-Weiner, 2015). The involvement of leading and experienced practitioners in the educational process is aimed at benefiting the students with updated job-related knowledge and real-life job experience (Nikolayeva, 2018; Rajesh, 2017). However, the core (credit-bearing) disciplines that are of practical job-related purpose for the students are often delivered by lecturers who are 'bookish professionals' in the field they are performing in (Chan, 2018). Even more importantly, the university curriculum is found to be overcrowded with theoretical disciplines that are quite arguably applicable in real-life professional settings (Adolfsson, 2018). The overtheorisation of studies discourages students from self-development in their professional field, demotivates them as student researchers, and causes a certain extend of disrespect to the lectures (Kormoczi, 2019). The above mentioned has created a potential gap for the research which is to address the topic of reshaping the university curriculum through the visiting lectureship to influence students', professional self-development, self-directed learning and selfeducation skills, research activeness, and professional socialisation. The research is also significant because it addresses some current challenges forming a crisis of higher education such as an instructional challenge, a fiscal challenge, a birth rate-related challenge, and a graduate employment challenge (Drozdowski, 2020).

\section{Literature Review}

The social constructivist approach to learning that is based on visiting or guest lectureship serves as a theoretical framework for the study (Al-Huneidi \& Schreurs, 2012; Yadav, 2016). It is based on learning from the interactive 
environment created by the instructor or the guest speaker (Ardiansyah \& Ujihanti 2018; Fernando \& Marikar, 2017). Visiting or guest lectureship and professorship sessions are seen as one of the applications of the social constructivism approach to creating a structured educational environment to train tertiary students as professionals-to-be (Hover \& Hicks, 2017; Mohammed et al., 2020). The visiting or guest lecturers can be both academic and nonacademic experts who are involved in sharing their expertise, job-related, or research skills and knowledge (Guest lecturer, 2020). The tenured position for visiting lectures is found to be quite often offered at universities (Himmelsbach, 2019).

In the literature, the guest speaker sessions and/or visiting lectureship at higher educational institutions are found to be revealed as an extra-curriculum framed learning component that is organised in the non-formal educational settings (Xhomaqi et al., 2019). The online environment based on the guest online lecturing is also seen by the researchers and educational practitioners as a pedagogic tool, which is capable to improve the quality of university education in various ways such as positive emotions motivating students to learn, alternative opinions, and expertise of the guest speakers combined with less academic (conventional) teaching methods (Varvel, 2020). The reshaping of the curriculum-driven by the introduction of visiting lectureship is found to be consistent with the concept of the critical approach to the curriculum upgrade (Geduld \& Sathorar, 2016). According to Foley et al. (2015), critical pedagogy is supposed to transform the curriculum in a way it provides a model to build the learning environment where the obtained knowledge is given a meaning that comes from negotiations and debates.

The purpose of the study is to investigate how visiting lectureship is capable to reshape and improve the university curriculum for four different majors such as educational policy, instruction, healthcare, and technology. In this light, the following research questions sought to explore:

1) How does visiting lectureship influence students' research activeness, professional self-development, self-directed learning \& self-education skills, and professional socialisation? and

2) How do students, lecturers, and representatives perceive the visiting lectureship of the host organizations?

\section{Methodology}

\subsection{Research Design}

The study is divided into six phases that utilised two designs namely: the exploratory and quasi-experimental ones. The phases include a baseline study, pre-test phase, intervention, post-test phase, focus group surveys, and data processing phases (see Fig 1.). 


\begin{tabular}{|c|c|c|c|}
\hline Phase 1 & \multicolumn{3}{|c|}{$\begin{array}{l}\text { Baseline study (4 weeks, } n=431 \text { students and lecturers) } \\
\text { Survey: purposes: a) to evaluate feasibility of reshaping the curriculum. b) to identify perceptions } \\
\text { of the students' engagement in their specialism-related component of studies and applied } \\
\text { research in terms of the students' research activeness, professional self-development, self-directed } \\
\text { learning \& self-education skills, and professional socialisation. }\end{array}$} \\
\hline Phase 2 & $\begin{array}{l}\text { Pre-test phase ( } \approx 4 \text { weeks) } \\
\text { 1. Sampling. } \\
\text { 2. Pre-test measurements to } \\
\text { identify the sample homogeneity. } \\
\text { 3. Data processing. }\end{array}$ & \multicolumn{2}{|c|}{$\begin{array}{l}\text { Transitional steps } \\
\text { 1. Data collection tools design. Assessment of the } \\
\text { credibility and eligibility of tools. } \\
\text { 2. Informed consent from the students and lecturers } \\
\text { obtained. } \\
\text { 3. The approval of the intervention programme by } \\
\text { the Board of Academics. }\end{array}$} \\
\hline Phase 3 & \multicolumn{2}{|c|}{$\begin{array}{l}\text { Intervention phase ( } 20 \text { weeks) } \\
\text { 1. Conventional training + lectures delivered by vising speakers } \\
\text { at universities and online. } \\
\text { 2. Mind sessions conducted by the invited lecturers and speakers. } \\
\text { 3. On-site hands-on experiences } \\
\text { 4. Mentoring (job-embedded experiences) } \\
\text { 5. Professionalism-related workshops }\end{array}$} & $\begin{array}{l}\text { Controlled } \\
\text { observations }\end{array}$ \\
\hline Phase 4 & \multicolumn{3}{|c|}{ Post-test phase ( 2 weeks) } \\
\hline Phase 5 & $\begin{array}{l}\text { Focus group interviews }(\approx 3 \mathrm{w} \\
\text { 1. Recording the interviews. } \\
\text { 2. Transcribing the audio. } \\
\text { 3. Synthesising the data. } \\
\text { 4. Consolidating the data. }\end{array}$ & & \\
\hline Phase 6 & $\begin{array}{l}\text { Data processing phase }(\approx 3 \text { we } \\
\text { 1. Data consolidation. } \\
\text { 2. Data computation. } \\
\text { 3. Data interpretation and reportin }\end{array}$ & & \\
\hline
\end{tabular}

Figure 1: Research design that is based on six stages such as a baseline study, pretestphase, intervention, post-test phase, focus group surveys, and data processing phases

The research lasted for 9 months. The baseline study takes place on June 2019 . The intervention lasted from October 2019 to the end of March 2020. The posttest measurements and focus group interviews are both administered online in June 2020. Phase six of the study is conducted during September 2020. The baseline study survey is anonymously administered online to the students and lecturers of ten universities in Ukraine such as National Pedagogical Dragomanov University, Kyiv; National University "Yuri Kondratyuk Poltava Polytechnic", Poltava; the National University of Life and Environmental Science of Ukraine, Kyiv; Khmelnytskyi National University, Khmelnytskyi; Taras Shevchenko National University of Kyiv, Kyiv; Dnipro Academy of Continuous Education for Dnipropetrovsk Regional Council, CommunallyOwned Institution of Higher Education, Dnipro; Kherson State University, Kherson; Kryvyi Rih Pedagogical University, Kryvyi Rih; Vinnytsia Mykhailo Kotsiubynskyi State Pedagogical University, Vinnytsia; and Sumy State 
University, Sumy. The institutions for the baseline study are intentionally selected to cover four different educational programmes that were intended to qualify the students in educational policy, instruction, healthcare, and technology. These are chosen because they correspond to the research team members' majors.

\subsection{Research Methods and Data Collection Instruments}

This study combines exploratory and quasi-experimental research methods. The exploratory methodology is used because it helps in analysing participants' opinions and perceptions expressed in words and actions (Mohajan, 2018; Aspers \& Corte, 2019). The quasi-experimental research method on the other hand is employed to complete the quasi-experiential measurements. Important data are drawn from the assessment of students' research skills and activeness, professional self-development, self-directed learning \& self-education skills, and professional socialisation by students themselves and their teachers before and after the intervention. The stakeholders' perceptions of visiting lectureship such as students, lecturers, and representatives of the host organisations are studied using the focus group interviews (See Appendix A). Baseline Study Survey Questionnaires (BSSQ) on Perceived Students' Engagement in Specialism-related Studies for the student and lecturer respondents (See Appendixes B \& C) is the research tool used in this study. The students' research skills are measured using a Questionnaire to Measure Research Skills (QMRS) which is designed and validated by Alvarado et al (2016). The students' research activeness is assessed by their scientific supervisors using the checklist (See Appendix D). A Professional Self-development Critical Reflection Scale (PSCRS) is indeed originally designed and validated to be a psychometrically sound tool which is purposefully used as a self-report questionnaire to measure the variable of students' professional self-development (see Appendix E). When drafting this research tool, the research team uses the ideas of Nickel (2013). Self-directed learning and self-education skills are measured with the Self-directed Learning Skills Scale (SLSS) that is constructed and validated by Ayyildiz and Tarhan (2015). The Readiness for Interprofessional Learning Scale (RIPLS) being outlined by Curran et al (2008) is modified to make measurements of the professional socialisation variable (see Appendix F).

The Voyant Tools which are accessed through the link: https://voyanttools.org/, are used to analyse the text corpus of teachers' observation reports obtained from the controlled observations. The consolidated data drawn from the measurements of the variables were computed using the IBM SPSS Statistics (25.0.0.1) package.The QMRS includes 20 items to cover such skills as information seeking and processing, managing data, and developing scientific information (Alvarado, León \& Colon, 2016). The benchmark values for the reliability of the QMRS are proved to be as follows: Cronbach's alpha coefficient for the total scale was .91. The value for the domain of information seeking and processing was .891. It was .711 for managing the data domain. It was supposed to be .687 for the domain of developing scientific information. 
The BSSQs, the checklist for students' scientific supervisors, RIPLS, and the focus group survey questionnaire are all validated by three Ph.D. experts in Social Studies. The tools are assessed for face validity, content validity, the internal consistency using Cronbach's Alpha. The Principal components analysis is also conducted to measure the validity of the tools. The three level-scale is suggested by the experts to unify the measurements and is applied to the tools that are designed for the study. For the BSSQs, it was 80-125 = a high rate of engagement; $51-79=\mathrm{a}$ moderate rate of engagement; $25-50=$ low rate of engagement. It was 25-35 = a high rate of activeness; $13-24=$ a moderate rate of activeness; and 7-12 = a low rate of activeness for the checklist for the scientific supervisors to assess the students' research activeness. For the PSCRS, it was 17$25=$ a high rate of $\mathrm{Ss}^{\prime}$ critical reflection on self-development; 10-16 = a moderate rate of Ss' critical reflection on self-development, and 5-9 = low rate of Ss' critical reflection on self-development. For the RIPLS, it was 17-25 = a high rate of Ss' readiness; $10-16=$ a moderate rate of Ss' readiness, and 5-9 $=$ low rate of Ss' readiness.

\subsubsection{The Focus Group Survey Questionnaire $(N=11)$}

It is based on 5 open-ended questions (See Appendix A )that are framed to cover different aspects of the respondents' perceptions of the programme reshaped to incorporate activities and events delivered by visiting speakers and guest lecturers. The respondents are randomly sampled for the interview. Each question in the interview is conducted via the phone and iss recorded and then transcribed. The responses were grouped according to the themes that were assigned by the experts with the code.

\subsection{Sampling}

Random sampling is used for the respondents to answer anonymously the questions from the online survey questionnaire used in the baseline study. The sample included 431 students and lecturers of ten universities. The invitation to take part in the survey is sent by email. The email addresses of students and lecturers were enquired from the Dean's offices of the institutions. The convenience sampling technique is actually used to hire students, lecturers, and representatives of the host organisations for the intervention phase of the study (Taherdoost, 2016). The students and lecturers of five universities are the subjects for the intervention. These universities are as follows: National Pedagogical Dragomanov University (NPDU), National University "Yuri Kondratyuk Poltava Polytechnic" (NUPP), National University of Life and Environmental Science of Ukraine (NULESU), Khmelnytskyi National University (KNU), and Taras Shevchenko National University of Kyiv (TSNUK). The Sample size calculator that can be accessed via the link: https://www.surveysystem.com/sscalc.htm\#two, is used to compute whether the number of hired students and lecturers is adequate for the experiment. It is found that the sample size of 184 individuals (169 students and 15 lecturers) is sufficient for the experiment if MOE (margin of error) is 5.48 and confidence level is $95 \%$. The demographic characteristics of the students and lecturers are presented in Table 1. 
Table 1: Demographic features of the sampled students $(N=169)$ and lecturers $(N=15)$

\begin{tabular}{|c|c|c|c|c|c|c|c|c|}
\hline \multirow{2}{*}{ Feature } & & \multicolumn{5}{|c|}{ Institution } & \multirow{2}{*}{$\%$} & \multirow{2}{*}{$\begin{array}{c}p- \\
\text { value* }\end{array}$} \\
\hline & & NPDU & NUPP & NULESU & KNU & TSNUK & & \\
\hline \multirow{2}{*}{$\begin{array}{l}\text { Gender } \\
\text { (students) }\end{array}$} & Males & 3 & 11 & 15 & 52 & 6 & 51.47 & \multirow{2}{*}{$\begin{array}{l}p \\
<0.001\end{array}$} \\
\hline & Females & 20 & 33 & 1 & 15 & 13 & 48.53 & \\
\hline \multirow{2}{*}{$\begin{array}{l}\text { Gender } \\
\text { (lecturers) }\end{array}$} & Males & 2 & 1 & 1 & 2 & 2 & 53.33 & \multirow{2}{*}{$\begin{array}{l}p \\
<0.001\end{array}$} \\
\hline & Females & 1 & 1 & 2 & 2 & 1 & 46.67 & \\
\hline \multirow{6}{*}{$\begin{array}{l}\text { Age } \\
\text { (students) }\end{array}$} & $18-25$ & 2 & 44 & 16 & 37 & 2 & 59.76 & \multirow{6}{*}{0.512} \\
\hline & $26-30$ & 9 & 0 & 0 & 3 & 7 & 11.24 & \\
\hline & $31-35$ & 5 & 0 & 0 & 12 & 6 & 13.60 & \\
\hline & $36-40$ & 5 & 0 & 0 & 7 & 4 & 9.46 & \\
\hline & $41-45$ & 2 & 0 & 0 & 6 & 0 & 4.73 & \\
\hline & $46-59$ & 0 & 0 & 0 & 2 & 0 & 1.21 & \\
\hline \multirow{5}{*}{$\begin{array}{l}\text { Age } \\
\text { (Lecturers) }\end{array}$} & $26-30$ & 0 & 0 & 1 & 2 & 0 & 20.00 & \multirow{5}{*}{0.491} \\
\hline & $31-35$ & 1 & 0 & 0 & 0 & 1 & 13.34 & \\
\hline & $36-40$ & 0 & 1 & 1 & 0 & 1 & 20.00 & \\
\hline & $41-45$ & 1 & 1 & 0 & 1 & 1 & 26.66 & \\
\hline & $46-59$ & 1 & 0 & 1 & 1 & 0 & 20.00 & \\
\hline
\end{tabular}

Note: S=students; L=lecturers; NPDU=National Pedagogical Dragomanov University, NUPP=National University «Yuri Kondratyuk Poltava Polytechnic», NULESU=National University of Life and Environmental Science of Ukraine, KNU=Khmelnytskyi National University; TSNUK=Taras Shevchenko National University of Kyiv; * the result is significant at $p<.05$.

The pre-intervention measurements in students' research skills and activeness, professional self-development, self-directed learning and self-education skills, and professional socialisation using the below instruments show homogeneity among the students.

\section{Selection of the guest speakers and visiting lecturers}

Both participants and the research team are involved in the process of selecting the guest speakers and visiting lecturers. The criteria for shortlisting them are as follows:

a) strong brand in the media as an expert in the field;

b) background and experience;

c) charismatic character; and

d) age (30 to 50 years old).

The selection process is conducted in three important stages. First, searching the information about them on the web. Second, holding negotiations with them to reach consensus concerning the purpose of the study and their role in it, and third, polling the students to find out which speaker they are exposed to meet. The host organisations are also put on a vote to identify whether the students are interested in visiting them or not.

\subsection{A Brief Outline of the Programmes}

The key data about the educational programmes that are used as the experimental base are presented in Table 2 . 
Table 2: Data about the institutions, educational programmes, and organisations that provided visiting speakers and hosted students

\begin{tabular}{|c|c|c|c|c|}
\hline $\begin{array}{l}\text { Institution } \\
\text { (head of the } \\
\text { programme) }\end{array}$ & Programme & مَ & Qualification & $\begin{array}{l}\text { Organisations to provide } \\
\text { visiting speakers and to host } \\
\text { students }\end{array}$ \\
\hline $\begin{array}{l}\text { NPDU } \\
\text { (Dr. V. I. } \\
\text { Bobrytska) }\end{array}$ & $\begin{array}{l}\text { "Educational } \\
\text { policy" Master's } \\
\text { programme }\end{array}$ & 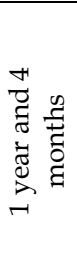 & $\begin{array}{l}\text { Educational expertise } \\
\text { and consultancy }\end{array}$ & $\begin{array}{l}\text { Directorate of higher education and } \\
\text { adult education and Directorate for } \\
\text { strategic planning and European } \\
\text { integration for the Ministry of } \\
\text { Education and Science of Ukraine, and } \\
\text { National Agency for Quality } \\
\text { Assurance of Higher Education of } \\
\text { Ukraine }\end{array}$ \\
\hline $\begin{array}{l}\text { NUPP } \\
(\mathrm{N} / \mathrm{A})\end{array}$ & $\begin{array}{l}\text { "Physical } \\
\text { therapy, } \\
\text { occupational } \\
\text { therapy" } \\
\text { Bachelor's } \\
\text { programme }\end{array}$ & 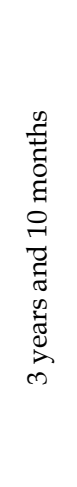 & $\begin{array}{l}\text { Assistance to a } \\
\text { physical therapist or } \\
\text { an occupational } \\
\text { therapist }\end{array}$ & $\begin{array}{l}\text { Poltava State Experimental Prosthetic } \\
\text { and Orthopedic Enterprise; } \\
\text { "Skalyansky Clinic" Medical Centre, } \\
\text { LLC.; Poltava City Centre for } \\
\text { Comprehensive Rehabilitation for } \\
\text { Persons with Disabilities; } \\
\text { Rehabilitation centre for children with } \\
\text { organic lesions of the nervous system } \\
\text { of Poltava Regional Children's Clinical } \\
\text { Hospital; "Sunflower" Training and } \\
\text { Rehabilitation Centre, NGO; "3rd City } \\
\text { Clinical Hospital for Poltava City } \\
\text { Council", Communally-owned and } \\
\text { subsidised enterprise }\end{array}$ \\
\hline $\begin{array}{l}\text { NULESU } \\
(\mathrm{N} / \mathrm{A})\end{array}$ & $\begin{array}{l}\text { "Automation } \\
\text { and computer- } \\
\text { integrated } \\
\text { technologies" } \\
\text { Bachelor's \& } \\
\text { Master's } \\
\text { programme }\end{array}$ & 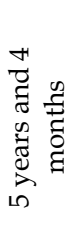 & $\begin{array}{l}\text { Engineers in } \\
\text { automation and } \\
\text { computer-integrated } \\
\text { technology }\end{array}$ & $\begin{array}{l}\text { "Greenhouses of Ukraine" Association, } \\
\text { "Greenhouse" Combine, PJSC; “S- } \\
\text { Engineering" Company; Siemens, } \\
\text { Schneider Electric }\end{array}$ \\
\hline $\begin{array}{l}\text { KNU } \\
\text { (Dr. H. V. } \\
\text { Krasylnykova) }\end{array}$ & $\begin{array}{l}\text { "Technology of } \\
\text { light industry } \\
\text { products } \\
\text { (garments)" } \\
\text { Master's } \\
\text { programme }\end{array}$ & 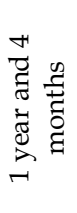 & $\begin{array}{l}\text { Instructor, } \\
\text { production control } \\
\text { engineer, } \\
\text { clothing designer \& } \\
\text { technologist }\end{array}$ & $\begin{array}{l}\text { Khmelnytsky Centre for Vocational } \\
\text { Education in the field of services; } \\
\text { Scientific and Methodological Centre } \\
\text { for Vocational Education and Training } \\
\text { of Engineers and Instructors in } \\
\text { Khmelnytsky Region }\end{array}$ \\
\hline $\begin{array}{l}\text { TSNUK } \\
\text { (E. Spitsyn, } \\
\text { Ph.D.) }\end{array}$ & $\begin{array}{l}\text { "Pedagogics of } \\
\text { higher school" } \\
\text { Master's } \\
\text { programme }\end{array}$ & 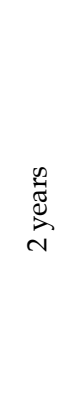 & $\begin{array}{l}\text { Teaching of } \\
\text { humanitarian } \\
\text { disciplines, } \\
\text { educational } \\
\text { disciplines, } \\
\text { natural disciplines, } \\
\text { social and } \\
\text { behavioural } \\
\text { disciplines }\end{array}$ & $\begin{array}{l}\text { Khmelnytskyi National University, } \\
\text { Khmelnytskyi, Ukraine; Dnipro } \\
\text { Academy of Continuous Education for } \\
\text { Dnipropetrovsk Regional Council, } \\
\text { Communally-Owned Institution of } \\
\text { Higher Education, Dnipro; Kherson } \\
\text { State University, Kherson; Kryvyi Rih } \\
\text { Pedagogical University, Kryvyi Rih; } \\
\text { Vinnytsia Mykhailo Kotsiubynskyi } \\
\text { State Pedagogical University, } \\
\text { Vinnytsia; Sumy State University, } \\
\text { Sumy }\end{array}$ \\
\hline
\end{tabular}

\subsection{Ethical Considerations}

The informed consent and the consent for voluntary participation are obtained from the sampled students and lecturers prior to the study. The confidentiality and anonymity of their personal data are given high priority so that the participants and visiting lecturers are not subjected to the harm of their reputation and public image. The survey questionnaires are drafted and edited to avoid misleading, biased, discriminatory, or offensive formulations. The 
questionnaire for a focus group interview is designed to identify whether the views of the stakeholders involved in the study contradict.

\section{Results}

The study finds that visiting lectureship is capable to reshape and improve the university curriculum for four different majors such as educational policy, instruction, healthcare, and technology. This is proved by a series of measurements made in the baseline study whose aim is to identify whether the experiment is feasible, and in the pre-intervention and post-intervention stages to identify what changes visiting lectureship brought to the variables. The latter is followed by the administration of the focus group surveys to boost the validity of the above measurements. The below sub-sections present the results obtained at different phases of the study.

\subsection{Baseline study Results}

As mentioned above, the randomly chosen students and lecturers are surveyed using the originally designed questionnaire (see Appendix B). The key purpose of the baseline study is to evaluate whether the reshaping curriculum is a feasible solution. In this concern, it serves to identify how the students perceived the extent of their engagement in their specialism-related component of studies and applied research, and learn about how the lecturers perceived the extent of students' engagement in their specialism-related component of studies and applied research. Hence, the baseline study survey results shown from the perspective of students and lecturers are presented in Figure 2.
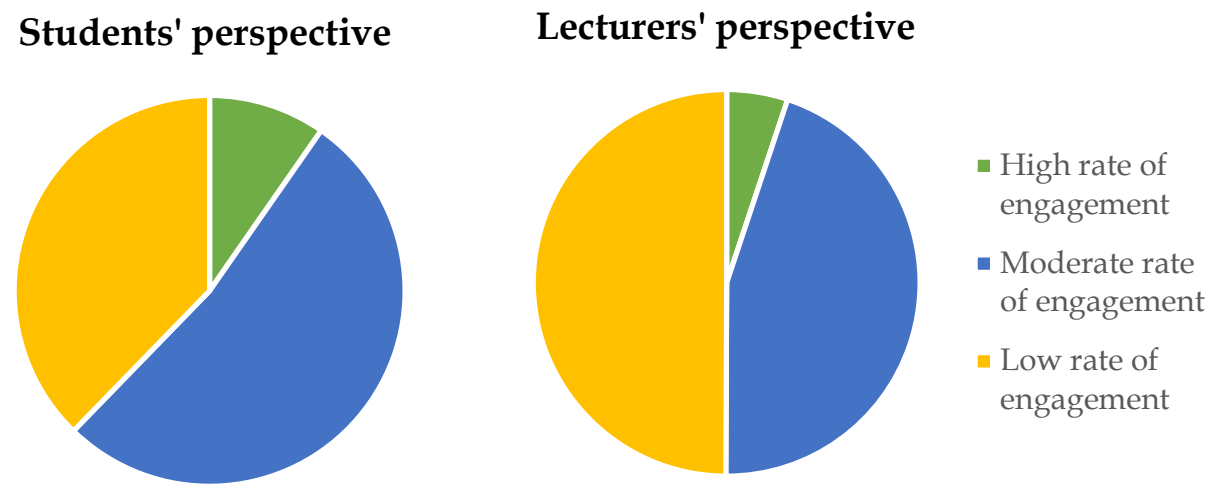

Figure 2: The baseline survey results shown form the perspective of students and lecturers

As can be seen in Fig 2., the rate for the perceived students' engagement in specialism-related studies as assessed by the students is mostly moderate, while that rate is mostly low from the lecturers' perspective.

\subsection{Pre-test and Post-test Measurements}

The pre-test and post-test results of measurements that are based on the QMRS, PSCRS, SLSS, RIPLS are dosplayed in Table 3. 
Table 3: The pre-test and post-test measurement results based on QMRS, PSCRS,

SLSS, RIPLS $(N=169)$

\begin{tabular}{|l|c|c|c|c|c|c|}
\hline \multirow{2}{*}{ Tool } & \multicolumn{2}{|c|}{ Pre-test } & \multicolumn{2}{c|}{ Post-test } & \multirow{2}{*}{ t-value } & \multirow{2}{*}{$\boldsymbol{p}$ - value $^{*}$} \\
\cline { 2 - 5 } & $\mu$ & SS & $\mu$ & SS & & \\
\hline QMRS & 41.31 & 1592.77 & 50.54 & 771.23 & -2.37125 & .013049 \\
\hline PSCRS & 38.23 & 1294.31 & 55.15 & 969.69 & -4.44225 & .000086 \\
\hline SLSS & 44.08 & 992.92 & 62.85 & 929.69 & -5.34641 & $<.00001$ \\
\hline RIPLS & 43.31 & 2286.77 & 61.67 & 129.69 & -4.96435 & .000023 \\
\hline
\end{tabular}

Note: $\mu$ - Mean; $S S$ - Sum of squares; *significant at $\mathrm{p}<.05$.

Students experience a positive change in all the variables under this study. The Mean values in Table 3 suggest that there is the most noteworthy improvement in the Ss' self-directed learning and self-education skills with an increase in values by 18.77 points. The second greatest change is in Ss' readiness for interprofessional learning (the professional socialisation variable) which signifies the difference of 18.36 points in pre-test and post-test measurements. The third significant change occurred in students' professional self-development intentions with 16.92 points of increase. The least change takes place in Ss' research skills with a positive shift of 9.23 points in this domain.

4.3. The assessment results of the students' research activeness by their scientific supervisors (ETCS-based)

Table 4 reflects the average students' scores for essays and research work.

Table 4: Results of the assessment of the students' research activeness by their scientific supervisors

\begin{tabular}{|c|c|c|c|c|c|}
\hline \multicolumn{2}{|c|}{ Pre-test } & \multicolumn{2}{c|}{ Post-test } & \multirow{2}{*}{ t-value } & \multirow{2}{*}{$\boldsymbol{p}$ - value $^{*}$} \\
\hline$\mu$ & SS & $\mu$ & SS & & \\
\hline 69.46 & 1305.23 & 83.62 & 605.08 & -4.04469 & .000235 \\
\hline
\end{tabular}

Note: $\mu$ - Mean; $S S$ - Sum of squares; *significant at $\mathrm{p}<.05$.

As can be seen in Table 4, the Mean scores for essays and the student research also imply that sampled students experienced a positive change.

\subsection{The Controlled Observations Reports}

The results of the analysis of the text corpus of teachers' observation reports obtained from the controlled observations using the Voyant Tools are presented in Fig. 3 and Table 5. In fact, Figure 3 shows the distribution of the mostly used words in teachers' observation reports. As displayed, the five most frequently used terms are benefits, job, practical, related, and specialism. 


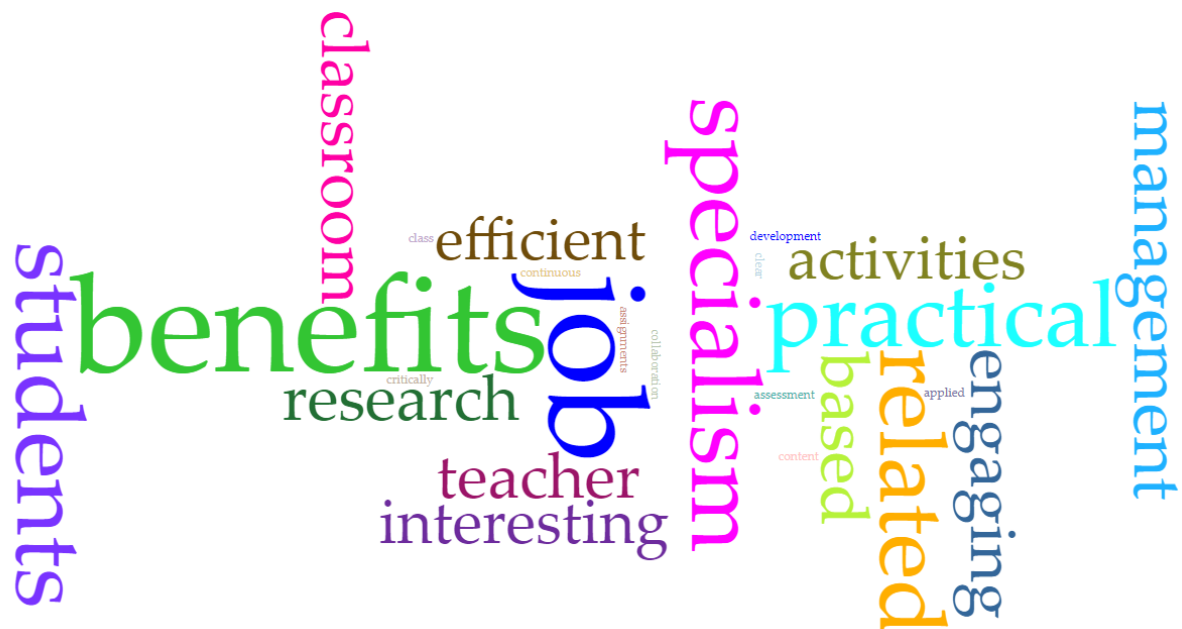

Figure 3: Distribution of the mostly used words in teachers' observation reports

The analysis of the correlation of terms is presented in Table 5.

Table 5: Results of the analysis of the correlation of terms

\begin{tabular}{|l|c|l|c|c|}
\hline \multicolumn{1}{|c|}{ Term 1 } & & \multicolumn{1}{c|}{ Term 2 } & Correlation & Significance $^{*}$ \\
\hline efficient & $\leftarrow \rightarrow$ & class/training & 1 & 0 \\
\hline benefits & $\leftarrow \rightarrow$ & Practical & 0.843 & 0.0021 \\
\hline interesting & $\leftarrow \rightarrow$ & Specialism & 0.763 & 0.0101 \\
\hline job & $\leftarrow \rightarrow$ & Related & 0.762 & 0.0103 \\
\hline activities & $\leftarrow \rightarrow$ & Research & 0.758 & 0.0352 \\
\hline specialism & $\leftarrow \rightarrow$ & Research & 0.739 & 0.0391 \\
\hline job & $\leftarrow \rightarrow$ & Benefits & 0.717 & 0.0416 \\
\hline
\end{tabular}

Note: the significance of .05 or less indicates a strong correlation; Correlation: the closer the value is to +1 , the stronger the correlation is.

As can be observed from Table 5, teachers' observation reports emphasise the effectiveness and benefits of the visiting lectureship for the students' occupational development and their research activity.

\subsection{Focus Group Survey Results ( $N=11$ respondents)}

The focus group includes 2 representatives of the host companies, 2 lecturers, 2 guest speakers, and 5 students. For the first question, all respondents appreciate the activities and events delivered by visiting speakers and guest lecturers. Some of their quotes were as follows:

[...the training sessions were based on the real cases...]

[...the programme included on-site assignments at host organisations that were quite challenging and beneficial in terms of the students' future job functions...]

As for the second question, students reporte that they have benefited professionally. The lecturers and guest speakers confesse that this teaching experience is a challenge to them because they need to update their teaching skills and knowledge along with reshaping the curriculum. The representatives 
of the host companies state that they could select the appropriate future employees for their organisations.

In the third question, the lecturers and speakers admit that they need more time to design lesson plans and training sessions. Students also acknowledge that the deadlines are quite tough to some extent. However, the host company representatives find nothings to criticise.

In reference to the fourth question, all the respondents state that they would become a referee for the programme reshaped in that way because the programme reshaped them as professionals and individuals.

As far as the last question is concerned, the lecturers suggest inviting the international speakers while the students proposed to use more media and technology, but the representatives of host companies advise launching the fundraising initiatives.

\section{Discussion}

The study is novel into two domains. First, it upgrades and updates the university curriculum of four different majors such as educational policy, instruction, healthcare, and technology through the use of visiting lectureship. Second, it identifies that the changes that have occurred in students' research activeness, professional self-development, self-directed learning and selfeducation skills, and professional socialisation are due to the use of visiting lectureship. The results obtained from the baseline study survey read that the rate for the perceived students' engagement in specialism-related studies as assessed by the students is mostly moderate, while that rate is mostly low from the lecturers' perspective. These suggest that the programme curriculum needs improvements and use of visiting lectureship could be incorporated in the programme to upgrade the content and teaching methods. The pre-test and post-test results of measurements that are based on the QMRS, PSCRS, SLSS, RIPLS prove that there is a positive change in all the variables under this study. Due to the intervention, there is the most noteworthy improvement in the Ss' self-directed learning and self-education skills with an increase in values by 18.77 points.

The second greatest change is in Ss' readiness for interprofessional learning (the professional socialisation variable) which indicates the difference of 18.36 points in pre-test and post-test measurements. The third significant change occurres in students' professional self-development intentions with 16.92 points of increase. The least change takes place in Ss' research skills with a positive shift of 9.23 points in this domain. The results of the analysis of the text corpus of teachers' controlled observation reports prove the effectiveness and benefits of the visiting lectureship for the students' occupational development and their research activity. The focus group interview also concludes that visiting lectureship is positively perceived by students, lecturers, and representatives of the host organisations.It is therefore safe to record that visiting lectureship positively influences not only the students but also the other educational stakeholders. 
More explicitly, it increases lecturers' motivation to provide a higher quality of instruction. Add to this, it benefits the potential employers as these are involved in the educational process at the early stage of the programme in its design and updating, which will result in a more competitive staff for them.

The results of the study align with the preceding research. It agrees with Khan and Zhang (2017) who consider the visiting lectureship leverage of upgrading the curriculum to bring benefits to the guest lecturer, students, and university. However, they emphasise that the recruitment process of guest speakers seems to be a challenge for the universities because of the curricula factor requiring the selection of a practitioner who is both an expert and a skilled instructor/trainer. The current study also agrees with James Jacob et al. (2015), who proves that both programme curriculum and teaching practices could be improved through applying a joint analysis approach based on sharing feedback between teachers and students. The scientists argue that holding special events such as seminars of visiting lecturers, workshops and best practices-to-share showcasing can be also beneficial for the educational stakeholders as these facilitate the open exchange of ideas and innovative practices in both learning and instruction. It is consistent with Nikolayeva (2018) who finds that guest speaker presentations delivered at the preparatory stage of the fulfillment of the students' research projects show a positive impact on students' motivation and quality of their course papers.

\section{Conclusion}

It is found that visiting lectureship reshapes and improves the university curriculum of four different majors such as educational policy, instruction, healthcare, and technology. Visiting lectureship positively influences students' research activeness, professional self-development, self-directed learning and self-education skills, and professional socialisation, and it is positively perceived by students, lecturers, and representatives of the host organisations. Visiting lectureship increases lecturers' motivation to provide a higher quality of instruction. Besides, it benefits the potential employers as these are involved in the educational process at the early stage of the programme in its design and updating, which will result in a more competent and competitive staff for them to hire. The results of the research imply that this instructional model can benefit all educational stakeholders through upgrading instructional methods, institutional fiscal management, and graduate employment opportunities. Further research is needed to investigate its impact on of the interprofessional learning.

\section{Recommendations}

It is also recommended to start with the needs analyses of the students and selecting the guest lectures through enquiring about their portfolio of trainings. Furthermore, it would be advisable for guest speakers to attend several lectures before conducting their sessions. 


\section{Acknowledgement}

We are grateful to the visiting speakers, guest lecturers and experts for valuable expertise in the evaluation of all outputs being obtained from the study. We are also thankful to all the sampled students, lecturers for their diligence, positive attitude, and encouraging behaviour that made the study smooth to complete.

\section{Conflicts of Interest}

No conflicts of interests of legal, financial, or commercial nature are reported by the authors.

\section{References}

Adolfsson, C. (2018). Upgraded curriculum? An analysis of knowledge boundaries in the teaching under the Swedish subject-based curriculum. The Curriculum Journal, 29(4), 442-440. https:/ / doi.org/10.1080/09585176.2018.1442231

Al-Huneidi, A., \& Schreurs, J. (2012). Constructivism based blended learning in higher education. International Journal of Emerging Technologies in Learning (iJET), 7(1), 49. https://doi.org/10.3991/ijet.v7i1.1

Alvarado, F. C., Leon, M. P., \& Colon, A. M. O. (2016). Design and validation of a questionnaire to measure research skills: experience with engineering students. Journal of Technology and Science Education, 6(3), 219-233. http://dx.doi.org/10.3926/jotse.227

Ardiansyah, W., \& Ujihanti, M. (2018). Social constructivist learning theory and reciprocal teaching to teach reading comprehension. International Journal of Learning and Teaching, 10(1), 70-77. https://doi.org/10.18844/ijlt.v10i1.3147

Aspers, P., \& Corte, U. (2019). What is qualitative in qualitative research. Qualitative Sociology, 42, 139-160. https://doi.org/10.1007/s11133-019-9413-7

Ayyildiz, Y., \& Tarhan, L. (2015). Development of the self-directed learning skills scale. International Journal of Lifelong Education, 34(6), 663-679. https://doi.org/10.1080/02601370.2015.1091393

Bobrytska, V. I. (2017). Profesiyna pidhotovka mahistriv u haluzi osvty v Ukraini: suchasni vyklyky, problemy, znakhidky [Occupational training of the students obtaining master's degree in the instructional field in Ukraine: challenges, problems, findings]. Vistnyk Natsionalnoho Aviatsiynoho Universitetu - Proceedings of the National Aviation University. Series: Pedagogy, Psychology, 10, 1-6. https://doi.org/10.18372/2411-264x.10.12457

Chan, C. (2018). Work experience should be a job requirement for academics. Retrieved from https://www.timeshighereducation.com/opinion/work-experience-should-bejob-requirement-academics

Curran, V. R., Sharpe, D., Forristall, J., \& Flynn, K. (2008). Attitudes of health sciences students towards interprofessional teamwork and education. Learning in Health and Social Care, 7(3), 146-156. https://doi.org/10.1111/j.1473-6861.2008.00184.x

Drozdowski, M. J. (2020). Higher education in crisis. https://www.bestcolleges.com/blog/higher-education-crisis/

Edgar, T. W., \& Manz, D. O. (2017). Chapter 4 - Exploratory Study. In: T. W. Edgar \& D. O. (Eds.), Manz, Research Methods for Cyber Security (pp. 95-130). Elsevier. https://doi.org/10.1016/B978-0-12-805349-2.00004-2

Fernando, S., \& Marikar, F. (2017). Constructivist teaching/learning theory and participatory teaching methods. Journal of Curriculum and Teaching, 6(1), 110-122. https://doi.org/10.5430/jct.v6n1p110 
Foley, J. A., Morris, D., Gounari, P., \& Agostinone-Wilson, F. (2015). Critical education, critical pedagogies, Marxist education in the United States. Journal for Critical Education Policy Studies, 13(3), 110-144. Retrieved from http://www.jceps.com/wp-content/uploads/2015/12/13-3-7.pdf

Geduld, D., \& Sathorar, H. (2016). Leading curriculum change: Reflections on how Abakhwezeli stoked the fire. South African Journal of Education, 36(4), 113. https://dx.doi.org/10.15700/saje.v36n4a1319

Guest lecturer. (2020). Guest Lecturer. Retrieved from https://www.zippia.com/guest-lecturer-jobs/

Himmelsbach, V. (2019). How to become a tenure track professor. Retrieved from https://tophat.com/blog/tenure-track-professor/

Hover, S., \& Hicks, D. (2017). The Wiley Handbook of Social Studies Research. In M. McGlinn Manfra \& C. Mason Bolick (Eds.), Social constructivism and student learning in social studies, https://doi.org/10.1002/9781118768747.ch12

James Jacob, W., Xiong, W., \& Ye, H. (2015). Professional development programmes at world-class universities. Palgrave Communications 1. https://doi.org/10.1057/palcomms.2015.2

Khan, S. A. R., \& Zhang, Y. (2017). The effective role of visiting lecturers in the courses of supply chain management. American Journal of Traffic and Transportation Engineering, 2(6), 104-109. https:/ / doi.org/ 10.11648/j.ajtte.20170206.12

Kormoczi, R. (2019). The problem with theoretical learning. Retrieved from https://www.timesinternational.net/theoretical-learning/

Leventhal-Weiner, R. (2015). America's "visiting professor" scam: How colleges are watering down higher education. Retrieved from https://www.salon.com/2015/02/19/americas_visiting_professor_scam_how_ colleges_are_watering_down_higher_education/

Mohajan, H. K. (2018). Qualitative research methodology in social sciences and related subjects. Journal of Economic Development, Environment, and People, 7(1), 23-48. https://doi.org/10.26458/jedep.v7i1.571

Mohammed, Husam, S., \& Kinyo, L. (2020). The role of constructivism in the enhancement of social studies education. Journal of critical reviews, 7(7), 249-256. https://doi.org/10.31838/jcr.07.07.41

Nickel, J. (2013). Self-Assessment of Professional Growth Through Reflective Portfolios. Phronesis, 2(1), 67-79. https://doi.org/10.7202/1015640ar

Nikolayeva, L. (2018). Role of Guest Lecturer in Research Proposal Writing: Students' Perception. Arab World English Journal, 1, 24-36. https://doi.org/10.24093/awej/mec1.2

Organizing Academic Research Papers: Types of Research Designs (OARP) (2020). Sacred Heart University. Retrieved from https:/ / library.sacredheart.edu/c.php?g=29803\&p=185902

Rajesh. (2017). Benefits of guest lectures for students. Retrieved from https:// www.easymnotes.in/benefits-guest-lectures-students/

Taherdoost, H. (2016). Sampling methods in research methodology; How to choose a sampling technique for research. International Journal of Academic Research in Management, 5(2). 18-27. https://doi.org/10.2139/ssrn.3205035

Varvel, V. E. (2020). Guest lecturers in the online environment. Retrieved from https://www.uis.edu/ion/resources/tutorials/pedagogy/guest-lecturers-inthe-online-environment/

Xhomaqi, B., Todd, A., \& Boivin, P. (Eds.) (2019). 21st-century learning environments. Retrieved from http://1llplatform.eu/1ll/wp-content/uploads/2019/10/LLLPPosition-paper-21CLE.pdf 
Yadav, R. (2016). Role of constructivism in learning. International Journal of Educational Studies, 3(3), 93-96. Retrieved from https://esciencepress.net/journals/index.php/IJES/article/view/1591

\section{Appendix A}

1. What is your general impression of the programme accompanied by activities and events delivered by visiting speakers and guest lecturers? Why?

2. How did you personally benefit from the programme reshaped in this way? Suggest your reasoning.

3. What disappointed or discouraged you from participating in the activities and events delivered by visiting speakers and guest lecturers? Why?

4. Would you become a referee for the programme reshaped in this way? Why?

5. What would you change to the programme to make it more beneficial for the students? 